\title{
Effect of Non Enzymatic Antioxidants on Serum Glucose Level in Magra Rams in Arid Region of Rajasthan, India
}

\author{
Amit Kumar $^{1 *}$, Jitendra Singh Mehta ${ }^{2}$, Ashok Kumar ${ }^{3}$ and Govind Narayan Purohit ${ }^{2}$ \\ ${ }^{I}$ Department of VGO, PGIVER, Jaipur, RAJUVAS, Bikaner, India \\ ${ }^{2}$ Department of VGO, CVAS, Bikaner, RAJUVAS, Bikaner, India \\ ${ }^{3}$ CSWRI-ICAR, ARC, Bikaner, India \\ *Corresponding author
}

\begin{abstract}
A B S T R A C T
Keywords

Vitamin E,

Selenium, Vitamin

C, Magra rams,

Serum, Serum

glucose

Article Info

Accepted:

17 May 2019

Available Online:

10 June 2019

The study was designed to evaluate the effect of combination of vitamin E with selenium (Se) and vitamin C injections on serum glucose concentration in Magra rams. Twenty one Magra rams were randomly divided in three groups. The $1^{\text {st }}$ group $(n=7, C)$ was administered injection of normal saline $1 \mathrm{ml}$ SC once in a week as a placebo and was considered as a control. The rams of group $2^{\text {nd }}(n=7$, VES) were given injections of selenium and vitamin E (1.5 mg sodium selenite and tocopherol $50 \mathrm{mg} / \mathrm{ml}) 1 \mathrm{ml} \mathrm{SC}$ per animal once in a week. The rams of group $3^{\text {rd }}(\mathrm{n}=7)$ were given vitamin $C(250 \mathrm{mg}$ sodium ascorbete/ml), $8 \mathrm{ml} \mathrm{SC}$ per animal on alternate days. All the rams received the treatments for 45 days. The overall mean serum glucose concentration $(\mathrm{mg} / \mathrm{dL})$ was $52.59 \pm 0.62$, $61.18 \pm 0.91$ and $57.69 \pm 1.12$ in group C, VES and VC, respectively which was significantly $(\mathrm{P}<0.05)$ higher in group VES followed by $\mathrm{VC}$ than group $\mathrm{C}$. The results of this experiment inferred that injections of vitamin $\mathrm{E}$ with Se and vitamin $\mathrm{C}$ during breeding season improved the level of serum glucose in Magra rams of arid region of Rajasthan.
\end{abstract}

\section{Introduction}

The biochemical parameters are important for several reproductive functions and their deficiency impaired these functions as well as causes nutritional disorders (Mcdowell, 1992). Glucose, also called dextrose, one of the group of carbohydrates known as most abundant monosaccharide (Domb et al., 1998) which is main source of energy for animal cells. Through a series of complex biochemical reactions, the breakdown of glucose yields high-energy molecules called adenosine triphosphate (ATP). Vitamins and minerals play an important role in the physiology of animals. Vitamin E, the principal lipid-soluble antioxidant (Chow, 1991) combined with selenium increased serum glucose level probably by improving feed efficiency or the improvement in the overall animal health (Balicka-Ramisz et al., 2006; Mahmoud et al., 2014). Although, vitamin $E$ and Se directly affect the metabolism of carbohydrates, it is not clear whether increased glucose level directly or indirectly through increasing thyroxin and 
triiodothyronine hormones in supplemented animals (Mohri et al., 2011). Vitamin C is a water-soluble vitamin essential for the metabolism of many mammals (Padilla et al., 2007), who can synthesize ascorbic acid from glucose in liver (Combs, 2008). An increase in glucose concentration due to vitamin $\mathrm{C}$ acid supplementation has been reported by Abd-Allah and Zanouny (2014) probably due to decrease in glucose utilization.

Although both vitamins serve as free radical scavengers in biological system, vitamin $\mathrm{C}$ is hydrophilic and exerts its effect in the extracellular space, trapping radicals in the aqueous phase (Sulak et al., 2005), while vitamin $\mathrm{E}$ is a lipid soluble antioxidant within the cells, where the reactive metabolites are actually produced (Durak et al., 2009). This protective activity of vitamin $\mathrm{E}$ depends on vitamin $\mathrm{C}$ to recycle oxidized vitamin $\mathrm{E}$ (Gey, 1998). However, studies related to affecting serum concentration by vitamins and minerals in blood are limited (Mahmoud et al., 2013; Jafaroghli et al., 2014) in rams. Therefore, the present study was aimed to evaluate the effects of vitamin $\mathrm{E}$ with $\mathrm{Se}$ and vitamin $\mathrm{C}$ on serum glucose levels in Magra rams in arid region of Rajasthan.

\section{Materials and Methods}

The present study was undertaken in the department of Veterinary Gynaecology and Obstetrics, College of Veterinary and Animal Science, RAJUVAS and ICAR-CSWRI, ARC, Beechhwal, Bikaner during year 20172018.

\section{Housing and feeding management}

All the twenty one Magra rams were fed on the standard diet, formulated according to the requirement for mature ram suggested by Indian Council of Agricultural Research, New Delhi (ICAR, 2013). All the rams were maintained in identical nutritional and managerial condition. All rams were provided pasture grazing, free access to water and were remained separated from ewes throughout the period of study. During the experimental period, all rams were housed in separate groups in well ventilated sheds and were maintained under proper hygienic conditions. A general management program for deworming, disease prevention were followed during the experiment as prescribed by the health calendar of the institute to ensure that animals were remained in a healthy condition throughout the study.

\section{Experimental design}

Magra rams, aged between 1.5-2.5 years having weight around $40 \mathrm{~kg}$ reared at CSWRI, ARC, Beechhwal, Bikaner were randomly divided in three groups. The $1^{\text {st }}$ group $(\mathrm{n}=7)$ was administered injection of normal saline (without antioxidant administration) $1 \mathrm{ml} \mathrm{SC}$ as a placebo and was considered as a control (C). The rams of group $2^{\text {nd }}(n=7)$ were given injections of selenium and vitamin $\mathrm{E}(1.5 \mathrm{mg}$ sodium selenite and tocopherol $50 \mathrm{mg} / \mathrm{ml}$, Inj.Repronol, Cadila pharmaceuticals limited, Ahmedabad, India) $1 \mathrm{ml}$ SC per animal once in a week (Deori et al., 2014) and considered as group VES. The rams of group $3^{\text {rd }}(n=7)$ were given vitamin $\mathrm{C}$ (250mg sodium ascorbete/ml, Inj.ALPA- C, Alpa vet, Indore, India), $8 \mathrm{ml} \mathrm{SC}$ per animal on alternate days (Al-saab, 2015) and considered as group VC. The rams received the treatments for 45 days.

\section{Collection of blood samples and analysis}

Blood was collected twice in a week in sterilized $10 \mathrm{ml}$ tubes one month post treatment for 5 weeks from treated and untreated rams by jugular veinepuncture. The serum was separated at $1000 \mathrm{~g}$ for 20 minutes. Serum samples were analyzed to estimate 
glucose level by VetTest biochemistry analyser (IDEXX Laboratories, US) as per the manufacturer's subscribed procedure.

\section{Statistical analysis}

Data obtained were analyzed statistically by three way analysis of variance using $3 \times 5$ factorial design and correlation were obtained using the SPSS computer programme (version 25.0), based on the standard procedures outlined by Snedecor and Cochran (1994). The mean values were compared by using Duncan's multiple range test (DMRT) described by Duncan (1955).

\section{Results and Discussion}

The overall mean serum glucose concentration (mg/dL) was 52.59 \pm 0.62 , $61.18 \pm 0.91$ and $57.69 \pm 1.12$ in group C, VES and VC, respectively which was significantly $(\mathrm{P}<0.05)$ higher in group VES followed by $\mathrm{VC}$ than group $\mathrm{C}$ (Table 1; Fig. 1). The overall mean serum glucose concentration $(\mathrm{mg} / \mathrm{dL}) \quad$ was $58.96 \pm 1.15,61.2 \pm 1.46$, $57.03 \pm 1.4,54.24 \pm 0.94$ and $54.34 \pm 1.13$ during the $1^{\text {st }}, 2^{\text {nd }}, 3^{\text {rd }}, 4^{\text {th }}$ and $5^{\text {th }}$ week, respectively which differed significantly $(\mathrm{P}<0.05)$ between the weeks. During $2^{\text {nd }}$ week, overall mean serum glucose concentration was significantly $(\mathrm{P}<0.05)$ higher than rest of the weeks. The overall mean serum glucose concentration was significantly $(\mathrm{P}<0.05)$ higher during $1^{\text {st }}$ week than $4^{\text {th }}$ and $5^{\text {th }}$ week. The overall mean serum glucose concentration differed non significantly between $1^{\text {st }}$ and $3^{\text {rd }}$ week as well as between $3^{\text {rd }}, 4^{\text {th }}$ and $5^{\text {th }}$ week. Analysis of variance revealed significant $(\mathrm{P}<0.05)$ interaction between treatment groups and weeks (Table 1; Fig. 1).

The mean serum glucose concentration was significantly $(\mathrm{P}<0.05)$ higher in group VES followed by $\mathrm{VC}$ than group $\mathrm{C}$. The overall mean serum glucose concentration was significantly $(\mathrm{P}<0.05)$ different between the weeks whereas interaction between treatment groups and weeks also differed significantly $(\mathrm{P}<0.05)$. The significant increase in serum glucose concentration in Magra rams of VES group was coincided with finding of Mahmoud et al., (2013) who reported significantly increased serum glucose level treated after vitamin $\mathrm{E}$ plus Se injections in Ossimi rams. Similarly, vitamin $\mathrm{E}$ and $\mathrm{Se}$ supplementation resulted in higher level of glucose than control lambs and ewes (Avci et al., 2000; Pisek et al., 2008). This result stand with findings of Babe (2011) who showed significant increase in serum glucose level in vitamin $C$ treated heat stressed sheep compared with untreated control. In accordance to the present findings, an increase in glucose concentration due to ascorbic acid supplementation has been reported by Abd-Allah and Zanouny (2014) probably due to the decrease in glucose utilization. In contrast of present findings, vitamin E plus Se administration didn't affect serum glucose concentration in lambs (Soliman, 2015; Ibrahim, 2017) and buffalo calves (Shinde et al., 2008). Contrastingly, Konwar et al., (2017) observed significantly reduced serum glucose level in vitamin $\mathrm{C}$ treated swamp buffaloes.

Increased glucose concentration may be due to reduction of oxidative stress produced by heat stress (Bruno et al., 2006). The decrease in serum glucose level in the ascorbic acid supplemented groups could be due to effect of ascorbic acid in increasing insulin concentration and decreasing corticosterone level as reported by Sahin et al., (2003) and Gursu et al., (2004). The effect of coadministration of vitamin $\mathrm{E}$ and $\mathrm{Se}$ on carbohydrate metabolism is not clear though if the increase levels of thyroxin and triiodothyronine hormones in supplemented animals could result to higher levels of glucose. 
Table.1 Effect of vitamin E+Se and vitamin C on serum glucose concentration (mg/dl) in Magra rams (Mean \pm SE)

\begin{tabular}{|l|l|l|l|l|l|l|}
\hline \multirow{2}{*}{ Groups } & \multicolumn{5}{|c}{ Serum glucose concentration $(\mathbf{m g} / \mathbf{d l})$ during weeks (n=10) } & \multirow{2}{*}{ Over all } \\
\cline { 2 - 7 } & $\mathbf{1}$ & $\mathbf{2}$ & $\mathbf{3}$ & $\mathbf{4}$ & $\mathbf{5}$ & \\
\hline C & $54.93 \pm 1.5^{\mathrm{aA}}$ & $51.72 \pm 1.53^{\mathrm{aA}}$ & $51.29 \pm 1.43^{\mathrm{aA}}$ & $53.29 \pm 1.13^{\mathrm{abA}}$ & $51.72 \pm 1.23^{\mathrm{Aa}}$ & $52.59 \pm 0.62^{\mathrm{a}}$ \\
\hline VES & $63.29 \pm 1.6^{\mathrm{bC}}$ & $68.22 \pm 1.49^{\mathrm{bD}}$ & $62.43 \pm 2.28^{\mathrm{bBC}}$ & $57.93 \pm 1.49^{\mathrm{bAB}}$ & $54 \pm 0.96^{\mathrm{abA}}$ & $61.18 \pm 0.91^{\mathrm{c}}$ \\
\hline VC & $58.64 \pm 2.21^{\mathrm{abB}}$ & $63.64 \pm 2.11^{\mathrm{bC}}$ & $57.36 \pm 2.54^{\mathrm{bB}}$ & $51.5 \pm 1.79^{\mathrm{aA}}$ & $57.29 \pm 2.91^{\mathrm{bB}}$ & $57.69 \pm 1.12^{\mathrm{b}}$ \\
\hline Over all & $58.96 \pm 1.146^{\mathrm{B}}$ & $61.2 \pm 1.46^{\mathrm{C}}$ & $57.03 \pm 1.398^{\mathrm{AB}}$ & $54.24 \pm 0.943^{\mathrm{A}}$ & $54.34 \pm 1.133^{\mathrm{A}}$ & \\
\hline
\end{tabular}

Means having different superscripts in a column (small letter) differ significantly $(\mathrm{p}<0.05)$

Means having different superscripts in a row (capital letter) differ significantly $(\mathrm{p}<0.05)$

Means carrying different superscripts (small and capital letter both) have significant interaction $(\mathrm{p}<0.05)$

$\mathrm{n}=$ Number of serum samples

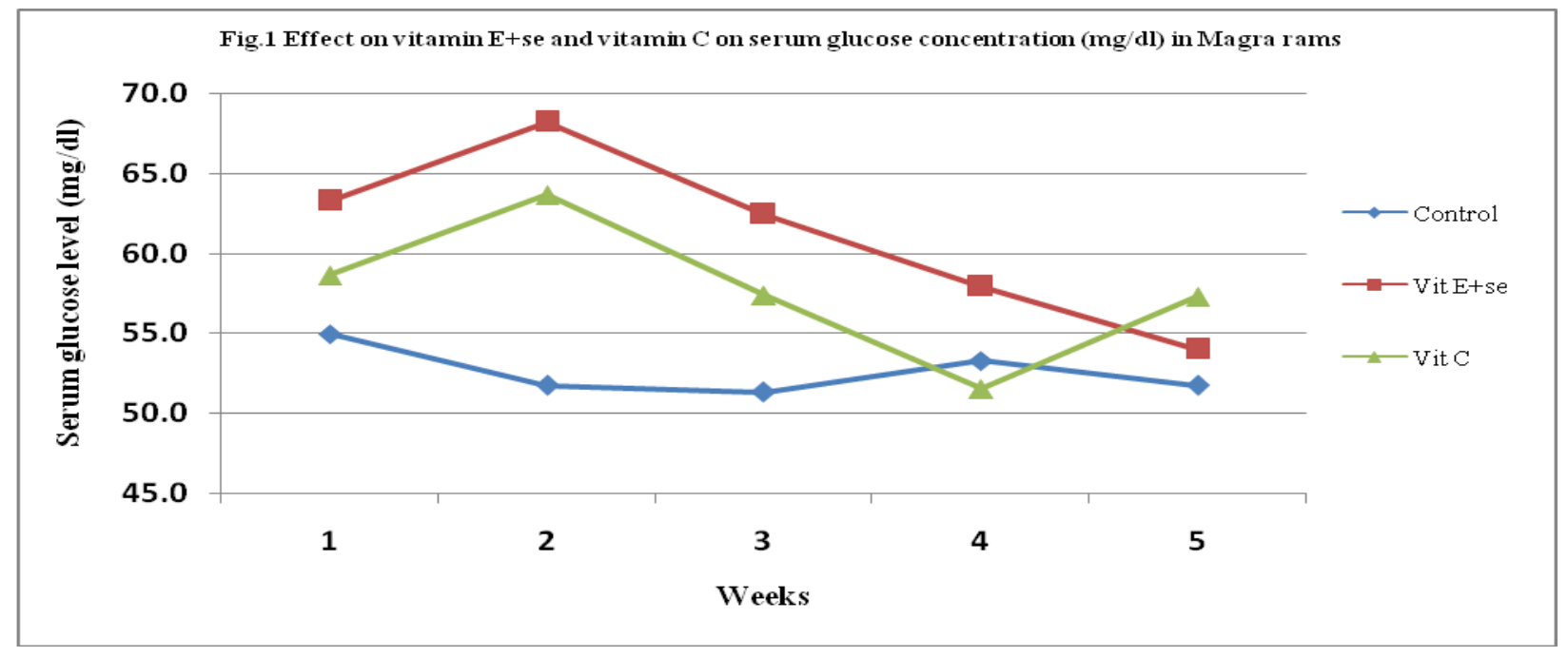

Mc Clure (1965) observed that variations in blood glucose were clearly linked to fertility as hypoglycemic condition has been found to depress the hypothalamic function leading to loss of gonadal activity due to failure of release of gonadotrophic hormone (Howland et al., 1966; Arthur, 1975). Since FSH and LH are glycoprotein, glucose is essential for biological activity of these hormones (Hafez et al., 2000). Therefore it can be inferred that administration of vitamin $\mathrm{E}$ with $\mathrm{Se}$ and ascorbic acid improve serum glucose concentration which is one of the essential metabolite in reproductive biology.

\section{Acknowledgment}

Authors are grateful to the Dean, CVAS, Bikaner, Head, department of VGO, CVAS,
Bikaner, Rajasthan for providing for providing financial and technical support. Authors are also thankful to the Director, CSWRI and Project Coordinator, NWPSI on Magra; Head, CSWRI-ARC Bikaner for providing animals and laboratory facilities during the research period.

\section{References}

Abd-Allah, M., and Zanouny A, I. 2014. Ameliorative effect of administration and chilled drinking water on ram lambs exposed to heat stress during summer season. Egyptian Journal of Sheep \& Goat Science.9: 17-28.

Al-saab, HKJ, 2015. Effect of vitamin C injection on semen quality of Awassi rams. Diyala Agricultural Sciences 
Journal 2015. 7: 1-19.

Arthur, G.H., 1975. Veterinary Reproduction and Obstetrics, 4th edn. The English Language Book Society and Bailliere, Tindall.

Avci, M., Z. Karakilcik and Kanat, R. 2000. Effects of vitamin A, E and selenium on reproductive performance and serum levels of some biochemical parameters in ewes, and birth weight and survival rates in their lambs. Turkish Journal of Veterinary and Animal Sciences 2000. 24: 45-50.

Babe, A.A. 2011. Effect of vitamin C on haematology and serum biochemistry in heat-stressed sheep. Research opinions in animal \& veterinary sciences.1: 731733.

Balicka-Ramisz, A., B. Pilarczyk, A. Ramisz and Wiecorek, M. 2006. Effects of selenium administration on blood serum Se content and on selected reproductive characteristics of sheep. Archiv Tierzucht. 49: 176-80.

Bruno, R.S., S.W. Leonard and Atkinson, J. 2006. Faster plasma vitamin E disappearance in smokers is normalized by vitamin $\mathrm{C}$ supplementation. Free Radical Biology and Medicine. 40: 689697.

Chow, C.K., 1991. Free Radical Biology and Medicine. 11: 215- 232.

Combs, G.F., 2008. Vitamin C. In: The Vitamins: Fundamental Aspects in Nutrition and Health, Combs, G.F. (Ed.). 3rd Edn., Academic Press, San Diego, CA., USA., pp: 235-263.

Deori, S., J. Bam and Paul, V 2014. Efficacy of prepartal vitamin $\mathrm{E}$ and selenium administration on fertility in Indian yaks (Poephagus grunniens oephagus grunniens). Veterinary Arhiv. 84: 513519.

Domb, A.J., J. Kost and Wiseman, D. 1998. Handbook of Biodegradable Polymers. p. 275.
Duncan, D.B., 1955. Multiple range and multiple F test. Biometrics. 11: 1-42.

Durak, D., F.G. Uzun, S. Kalender, A. Ogutcu, M. Uzunhisarcikli and Kalender, Y. 2009. Environmental Toxicology. 24: 235-242.

Gey, K.F., 1998. Biofactors. 7:113-74.

Gursu, M.F., M. Onderci, F. Gulcu and Sahin, K. 2004. Effect of vitamin C and folic acid supplementation on serum paraoxonase activity and metabolite induced by heat stress in vivo. Nutrition Research. 24: 157-64.

Hafez, E.S.E., M.R. Jainudeen and Rosnina, Y. 2000. Hormone, growth factors and reproduction. In: Reproduction in Farm Animals. Hafez, E.S.E and Hafez, E. B.(eds.), Seventh edn, Lippincott Williams and Wilkins, Philadephia, USA, pp. 33-54.

Hemila, H., P. Roberts and Wikstrom M.1985. FEBS Letter. 178: 25-30.

Howland, B.E., R.L. Kirkpatrick, A.L. Pope and Casida L. E. 1966. Pituitary and Ovarian Function in Ewes Fed on two nutritional Levels. Journal of Animal Science. 25: 716-721.

Ibrahim, E.M., 2017. Effect of parenteral supplementation of vitamin $\mathrm{E}$ plus selenium on nutrient digestibility, productive performance and some serum biochemical indicators of lambs. Egyptian Journal of Sheep \& Goat Science. 12: 59-70.

Jafaroghli, M., H. Abdi-Benemar, M.J. Zamiri, B. Khalili, A. Farshade and Shadparvar, A.A. 2014. Effects of dietary $n-3$ fatty acids and vitamin $C$ on semen characteristics, lipid composition of sperm and blood metabolites in fat-tailed Moghani rams. Animal Reproduction Science. 147:1724.

Konwar, D., T.K. Amonge, D.J. Dutta, A.K. Gogoi, R.S. Borah, G.C. Das, R. Bhuyan and Choudhury, R.R. 2017. 
Dietary Supplementation of Ascorbic Acid on Hemato-biochemical and Hormonal Parameters in Swamp Buffaloes. Journal of Animal Research. 7: 39-47.

Mahmoud, G.B., S.M. Abdel-Raheem and Hussein, H.A. (2013). Effect of combination of vitamin $\mathrm{E}$ and selenium injections on reproductive performance and blood parameters of Ossimi rams. Small Ruminant Research, 113: 103108.

Mahmoud, G.B., S.M. Abdel-Raheem and Hussein, H.A. 2014. Reproductive and physiological traits of ossimi rams as affected by vitamin $\mathrm{E}$ and selenium injection. Egyptian Journal of Animal Production. 51:99-105.

McClure, T.J., 1965. A nutritional cause of low non return rates in dairy herds. Australian veterinary journal. 41:199.

Mcdowell, L.R., 1992. Minerals in animal and human nutrition. Academic press Inc. Harcourt Brace Jovanovich. Publishers, San Diego, CA.

Mohri, M., A. Ehsani, M.A. Norouzian, M.H. Bami and Seifi, H.A. 2011. Parenteral selenium and vitamin $\mathrm{E}$ supplementation to lambs: hematology, serum biochemistry, performance, and relationship with other trace elements. Biological Trace Element Research. 139: 308-16.

Padilla, L., T. Matsui, S. Ikeda, M. Kitagawa and Yano, H. 2007. The effect of vitamin $\mathrm{C}$ supplementation on plasma concentration and urinary excretion of vitamin $\mathrm{C}$ in cattle. Journal of Animal Science. 85: 3367-3370.

Pisek, L., J. Travnicek, J. Salat, V. Kroupova and Soch, M. 2008. Changes in white blood cells in sheep blood during selenium supplementation. Veterinary Medicine 53: 255-259.

Sahin, K., N. Sahin and Kucuk, O. 2003. Effect of chromium and supplementation on growth, carcass traits, serum metabolite and antioxidant status of broiler chicken reared at high ambient temperature $\left(32^{\circ} \mathrm{C}\right)$. Nutrition Research. 23: 225-38.

Shinde, P.L., R.S. Dass, A.K. Garg and Bhadane, K.P. 2008. Effect of vitamin E and selenium supplementation on growth, nutrient utilization and their balance in male buffalo calves. Animal Nutrition and Feed Technology. 8: 135143.

Snedecor, G.W., and Cochran, W.G. 1994. Statistical methods, $9^{\text {th }}$ edition. The Lowa, State University Press, Ames, Lowa.

Soliman, E.B., 2015. Dose response of vitamin $\mathrm{E}$ and selenium injection on growth performance, physiological and immune response of Ossimi lambs. Egyptian Journal of Sheep \& Goat Science.10: 27-40.

Sulak, O., I. Altunta, N. Karahan, B. Yildirim, O. Akturk, H.R. Yilmaz and Delibas, N. 2005. Pesticides Biochemistry and Physiology. 83: 21-28.

\section{How to cite this article:}

Amit Kumar, Jitendra Singh Mehta, Ashok Kumar and Govind Narayan Purohit. 2019. Effect of Non Enzymatic Antioxidants on Serum Glucose Level in Magra Rams in Arid Region of Rajasthan, India. Int.J.Curr.Microbiol.App.Sci. 8(06): 2145-2150.

doi: https://doi.org/10.20546/ijcmas.2019.806.254 